\title{
Predictive values of C-reactive protein/albumin ratio in new-onset atrial fibrillation after coronary artery bypass grafting
}

\author{
Datih Aksoy ${ }^{1}$ \\ (D)Dinçer Uysal² \\ (D) Erdogan Ibrişim
}

1. Associate Professor from the Department of Cardiology, Suleyman Demirel University, Medical School, Isparta, Turkey. 2. Associate Professor from the Department of Cardiovascular Surgery, Suleyman Demirel University, Medical School, Isparta, Turkey. 3. Professor from the Department of Cardiovascular surgery, Suleyman Demirel University, Medical School, Isparta, Turkey.

http://dx.doi.org/10.1590/1806-9282.66.8.1049

\section{SUMMARY}

OBJECTIVE: This study aimed to investigate the predictive value of the newly defined C-Reactive Protein (CRP)/Albumin Ratio (CAR) in determining the development of atrial fibrillation (AF) in comparison with other inflammatory markers, such as Neutrophil/Lymphocyte (N/L) Ratio and Platelet/Lymphocyte (P/L) Ratio, in patients undergoing Coronary Artery Bypass Grafting (CABG) surgery.

METHODS: The population of this observational study consisted of 415 patients undergoing CABG. The study cohort was subdivided into two groups based on the development of AF. Complete blood counts, serum CRP, and serum albumin levels were evaluated before the CABG. The CAR, N/L, and P/L ratios of all the patients were calculated. Predictors of postoperative AF were determined by multiple logistic regression analysis (MLRA).

RESULTS: During follow-up, 136 patients (32.8\%) developed postoperative AF. With MLRA, independent risk factors for postoperative AF were determined as follows: fasting glucose level (OR: 1.01; $95 \%$ Cl: 1.00-1.01, $P<0.001$ ), age (OR: 1.12; $95 \%$ Cl: 1.07-1.17, $P<0.001$ ), left ventricle ejection fraction (OR: 0.90; $95 \%$ Cl: 0.87-0.94, $P<0.001$ ), male gender (OR: 3.32; $95 \%$ Cl: 1.39-7.90, $P=0.007$ ), 24-hour drainage amount (OR: 1.004; $95 \%$ Cl: 1.002-1.005, $P$ <0.001), and CAR (OR: 1.82; $95 \%$ Cl: 1.53-2.16, P <0.001). Receiver Operating Characteristic curve analysis showed that CAR (C-statistic: 0.75; 95\% Cl: 0.71-0.79, $p<0.001$ ) was a significant predictor of $A F$.

CONCLUSION: Novel inflammatory marker CAR can be used as a reliable marker to predict the development of AF following CABG.

KEYWORDS: Protein C. Albumins. Atrial fibrillation. Myocardial revascularization. Coronary artery bypass.

\section{INTRODUCTION}

Inflammation plays an important role both in the onset of Atrial Fibrillation (AF) and its maintenance through myocyte necrosis, fibrosis, and infiltration of inflammatory markers. ${ }^{1-3}$ Several inflammatory markers, including the High-Sensitive C-Reactive Protein (Hs-CRP) and Interleukin-6 (IL-6), levels were reported to be elevated in patients with different AF subtypes compared to those with sinus rhythm..$^{2-5}$

Postoperative atrial fibrillation (POAF) is a major and fatal complication of Coronary Artery Bypass Grafting (CABG) surgery. Patients developing Atrial Fibrillation (AF) after cardiac surgery have a higher

DATE OF SUBMISSION: 07-Jan-2020

DATE OF ACCEPTANCE: 26-Feb-2020

CORRESPONDING AUTHOR: Fatıh Aksoy

Suleyman Demirel Univesitesi Tip Fakultesi, Isparta, Turkey

Tel: +90 505 231-3661 / Fax: +90 246 232-4510

E-mail:dr.aksoy@hotmail.com 
risk of morbidities such as cerebrovascular events, pulmonary edema, longer hospital stays, and mortality compared to those who do not develop AF. ${ }^{6-8}$ Identifying the patients who may develop POAF before the surgery and taking the necessary precautions may decrease the mortality and morbidity rates. An association between POAF and inflammation has been shown in previous studies ${ }^{5,6}$. C-Reactive Protein (CRP)/ Albumin Ratio (CAR), a novel parameter of inflammation, has been shown to be superior to CRP or albumin levels alone in determining inflammatory status in several cardiovascular diseases. ${ }^{9,10}$ However there are no published studies on the association between CAR and POAF in the literature. In this study, we aimed to investigate the predictive value of CAR in the development of POAF.

\section{METHODS}

\section{Study population}

The study included patients who underwent isolated Coronary Artery Bypass Grafting (CABG) surgery at the Suleyman Demirel University, Education and Research Hospital between March 2017 and June 2019. The study population was retrospectively and consecutively analyzed by using a database that collated patient data as a part of routine clinical practice. The overall study population included 475 patients undergoing CABG. The exclusion criteria included hyperthyroidism, age $<18$ years, prior cardiac surgery, class III or IV heart failure, previous atrial fibrillation, left atrial diameter $>55 \mathrm{~mm}$, left ventricular ejection fraction $<0.25$, sepsis, heart rate $<60 \mathrm{bpm}$, systolic blood pressure $<90 \mathrm{~mm} \mathrm{Hg}$, inflammatory disease, pericarditis, patients undergoing off-pump surgery, and being on antiarrhythmic treatment. According to these criteria, 35 patients were excluded due to previous atrial fibrillation $(n=15)$, heart rate $<60 \mathrm{bpm}$ ( $\mathrm{n}$ $=5)$, hyperthyroidism $(n=5)$, left atrial diameter $>55$ $\mathrm{mm}(\mathrm{n}=5)$, ejection fraction $<0.25(\mathrm{n}=5)$, and patients undergoing off-pump surgery $(\mathrm{n}=25)$. Therefore, 415 patients were included in the final study cohort. Informed consent was obtained from each patient, and the study protocol conformed to the ethical guidelines of the 1975 Declaration of Helsinki as reflected in a priori approval by the institution's human research committee (Date: 28.05.2019, Decision no: 181). Similar operative techniques were used for all patients. A transthoracic echocardiogram was recorded for each patient before and after the surgery.

\section{Blood collection and laboratory analysis}

Blood samples were drawn from the antecubital vein by careful vein puncture using a 21-G sterile syringe without stasis at 08:00-10:00 $\mathrm{h}$ after a fasting period of $12 \mathrm{~h}$. Hematologic and biochemical measurements including liver enzymes were carried out. An automatic blood counter (LH 780 Hematology Analyzer, Beckman Coulter Inc., Miami, FL) was used for whole blood counts including total White Blood Cells (WBCs), hemoglobin, platelets, neutrophils, lymphocyte, and monocytes. Serum C-reactive Protein (CRP) levels were measured using BN2 Nephelometry Analyzer II (Dade Behring, Kalletal, Germany). The normal value for CRP is in the range of $0-6 \mathrm{mg} / \mathrm{L}$.

\section{Rhythm follow-up}

The rhythms were followed-up by continuous electrocardiogram monitoring during the patients' stay at the intensive care unit and by 24-hour Holter during the rest of hospitalization. A 12-lead electrocardiogram was used for recording routinely every morning and whenever the patients had symptoms suggestive of dysrhythmia. Atrial fibrillation was defined as an irregular rhythm with the absence of discrete $P$ waves in the 12-lead electrocardiogram. An atrial fibrillation episode lasting for at least 5 minutes during hospitalization was defined as POAF. ${ }^{11}$

\section{Statistical analysis}

Statistical Package Social Sciences (SPSS) software version 16.0 package and Medcalc version 15.2 were used for statistical analyses in this study. Categorical variables were expressed as frequency (\%) and compared using the $\chi 2$ test. The Kolmogorov-Smirnov test was used to test the distribution of numeric variables; those with normal distribution were expressed as mean \pm standard deviation and were compared with the Student's t-test. Data without normal distribution were expressed as median (Inter-quartile range (IQR) of 25\%-75\% percentiles) and were compared with the Mann-Whitney U test. In all statistical analyses, a P-value $<0.05$ was considered statistically significant. The correlations between CAR, presence of AF, and other clinical, laboratory, and echocardiographic parameters were measured by Pearson or Spearman correlation analysis when appropriate. Univariate analysis of binary logistic regression was performed to identify which factors are associated with incident AF. After including each of these potential confounding factors, backward conditional binary logistic 
regression analysis was performed to estimate the odds ratio $(\mathrm{OR})$ and $95 \%$ confidence interval $(95 \% \mathrm{CI})$ for incident AF. We used a receiver operating characteristic (ROC) analysis with area under the curve and CAR, CRP, and albumin cut-off points for prediction of AF. All ROC comparisons were performed using the DeLong test. Predictors of AF were determined by logistic regression analysis.

\section{RESULTS}

A total of 415 patients (mean age: $62.86 \pm 11.86$ years; range, 28-84 years) were included in this study. During the follow-up period, 136 patients (32.8\%) developed POAF. The demographic and clinical characteristics of the patients with and without POAF are listed in Table 1. The patients with POAF were significantly older and there were more males when

TABLE 1. DEMOGRAPHIC AND CLINICAL CHARACTERISTICS OF PATIENTS WITH AND WITHOUT AF.

\begin{tabular}{|c|c|c|c|}
\hline & Without AF $(n=279)$ & With AF $(n=136)$ & P-value \\
\hline Age (years) & $60.5 \pm 12.4$ & $67.5 \pm 8.9$ & $<0.001$ \\
\hline Body mass index & $29.0 \pm 5.2$ & $28.0 \pm 4.4$ & 0.05 \\
\hline Female gender (n, \%) & $90(32.3)$ & $26(19.1)$ & 0.003 \\
\hline Diabetes mellitus ( $n, \%$ ) & $114(40.9)$ & $73(53.7)$ & 0.009 \\
\hline Hypertension (n, \%) & $202(72.4)$ & $121(89.0)$ & $<0.001$ \\
\hline Congestive heart failure (n, \%) & $14(5.1)$ & $27(20.8)$ & $<0.001$ \\
\hline Peripheral vascular disease (n, \%) & $72(25.8)$ & $50(36.8)$ & 0.015 \\
\hline History of CVA (n, \%) & $36(13.8)$ & $24(21.8)$ & 0.04 \\
\hline Ejection fraction (\%) & $56.6 \pm 8.4$ & $50.3 \pm 10.0$ & $<0.0001$ \\
\hline Left atrial diameter (mm) & $39.1 \pm 6.1$ & $38.3 \pm 7.7$ & 0.289 \\
\hline $\operatorname{LVEDD}(\mathrm{mm})$ & $47.3 \pm 5.5$ & $46.9 \pm 4.9$ & 0.379 \\
\hline LVESD (mm) & $29.8 \pm 6.9$ & $31.7 \pm 5.6$ & 0.007 \\
\hline IVSD (mm) & $12.0 \pm 3.1$ & $12.6 \pm 3.4$ & 0.007 \\
\hline PWD (mm) & $11.1 \pm 2.2$ & $11.1 \pm 0.9$ & 0.988 \\
\hline $\operatorname{AoD}(\mathrm{mm})$ & $26.9 \pm 3.5$ & $26.8 \pm 3.3$ & 0.832 \\
\hline Total cholesterol (mg/dl) & $201.2 \pm 41.3$ & $196.9 \pm 39.4$ & 0.412 \\
\hline HDL cholesterol (mg/dl) & $41.8 \pm 10.2$ & $41.2 \pm 9.0$ & 0.632 \\
\hline LDL cholesterol (mg/dl) & $126.0 \pm 40.4$ & $124.3 \pm 41.5$ & 0.760 \\
\hline Triglycerides (mg/dl) & $158.2 \pm 104.1$ & $141.9 \pm 48.6$ & 0.187 \\
\hline Creatinine $(\mathrm{mg} / \mathrm{dl})$ & $1.0 \pm 0.3$ & $11.1 \pm 0.3$ & 0.103 \\
\hline Glucose $(\mathrm{mg} / \mathrm{dl})$ & $142.5 \pm 67$ & $198.6 \pm 119.9$ & $<0.001$ \\
\hline Lymphocyte $\left(10^{3} / \mu l\right)$ & $2556 \pm 0.978$ & $2576 \pm 1.063$ & 0.849 \\
\hline Platelet $\left(10^{3} / \mu \mathrm{l}\right)$ & $230 \pm 63$ & $232 \pm 78$ & 0.773 \\
\hline CAR, median (IQR) & $0.96(0.5-2.0)$ & $4.3(1.1-8.6)$ & $<0.001$ \\
\hline $\mathrm{N} / \mathrm{L}$ ratio & $3.3 \pm 3.1$ & $4.3 \pm 6.8$ & 0.05 \\
\hline P/L Ratio & $11.3 \pm 9.4$ & $140 \pm 17.2$ & 0.04 \\
\hline CRP (mg/l), median (IQR) & $4.00(2.00-8.00)$ & $16.00(4.25-33.0)$ & $<0.001$ \\
\hline Albumin $(\mathrm{g} / \mathrm{l})$ & $3.8 \pm 0.4$ & $3.7 \pm 0.3$ & 0.002 \\
\hline $\operatorname{WBC}\left(10^{3} / \mu \mathrm{l}\right)$ & $8952 \pm 4227$ & $8751 \pm 2240$ & 0.513 \\
\hline \multicolumn{4}{|l|}{ Operative and postoperative parameters } \\
\hline Cardiopulmonary bypass time (min) & $78.8 \pm 27.3$ & $86.8 \pm 39.6$ & 0,02 \\
\hline X Clamp time (min) & $47.5 \pm 18.8$ & $46.7 \pm 16.2$ & 0,686 \\
\hline 24-hour drainage (ml) & $28.2 \pm 14.5$ & $388.7 \pm 232.3$ & 0,003 \\
\hline 48-hour drainage (ml) & $147.8 \pm 83.9$ & $159.9 \pm 69.8$ & 0,148 \\
\hline Duration of the hospitalization at the intensive care unit (days) & $2.1 \pm 0.4$ & $2.6 \pm 1.4$ & $<0.001$ \\
\hline Bypass number (n) & $2.4 \pm 1.7$ & $2.6 \pm 2.1$ & 0.158 \\
\hline Reoperation due to hemorrhage (n, \%) & $6(2.2)$ & $2(1.5)$ & 0.985 \\
\hline Intraoperative mortality (n, \%) & - & - & \\
\hline In-hospital mortality (n, \%) & $8(2.9)$ & $6(4.4)$ & 0.786 \\
\hline
\end{tabular}

Data presented as mean \pm standard deviation, median (IQR) or number (\%) of the patients. CVA = cerebrovascular accident; $H D L=$ high-density lipoprotein; LVEDD = Left Ventricle end diastolic diameter; LVESD= Left Ventricle end systolic diameter; IVSD: interventricular septum diameter; PWD: Posterior wall diameter; AoD: aortic diameter; CAR: C reactive protein to albumin ratio; N: neutrophil; L: Lymphocyte; P: Platelet; WBC: White blood cell 
compared to patients without $\mathrm{POAF}(\mathrm{p}<0.001$ and $\mathrm{p}=$ 0.003 , respectively). The presence of diabetes mellitus, hypertension, congestive heart failure, peripheral vascular disease, and stroke/transient ischemic events was higher in patients with POAF compared to patients without POAF. There were no statistically significant differences in cholesterol parameters $(\mathrm{p}>$ 0.05 for all parameters) between patients with and without POAF. Left ventricle ejection fraction was significantly lower in patients with POAF compared to patients without POAF $(\mathrm{p}<0.001)$. Preoperative fasting glucose levels were higher in patients with POAF compared to patients without POAF $(p<0.001)$. There were no statistically significant differences in patients with and without POAF in whole blood parameters, including platelet $(\mathrm{P})$ count, white blood cell, neutrophil (N), and lymphocyte (L) level; however, the N/L and $\mathrm{P} / \mathrm{L}$ ratios were significantly higher in patients with POAF compared to patients without POAF ( $p=$ 0.05 and $p=0.04$ respectively.)

The postoperative drainage amounts in the first 24 and 48 hours were higher in patients with POAF than in patients without $\mathrm{POAF}(\mathrm{P}=0.003$ for 24 hours and $\mathrm{P}=0.148$ for 48 hours) (Table 1). Cardiopulmonary bypass time was longer in patients with POAF compared to patients without POAF $(\mathrm{P}=0.02)$ but there was no statistically significant difference in the clamp time between patients with and without POAF. The duration of hospitalization at the intensive care unit was longer in patients with POAF than in patients without POAF $(\mathrm{P}<0.001)$. There were no statistically significant differences in events such as reoperation due to hemorrhage, and intraoperative and in-hospital mortality (for all parameters $\mathrm{p}>0.05$ ) between patients with and without POAF (Table 1).

The median CAR and CRP levels were significantly lower in patients without POAF compared to patients with POAF [0.96 (0.5-2.0) versus 4.3 (1.1-8.6), $\mathrm{p}<0.001$ for CAR; $4.00 \mathrm{mg} / \mathrm{l}(2.00-8.00)$ versus $16.00 \mathrm{mg} / \mathrm{l} \mathrm{(4.25-}$ 33.0), $\mathrm{p}<0.001$ for CRP]. The mean albumin level was lower in patients with POAF compared to patients without POAF (3.8 \pm 0.4 versus $3.7 \pm 0.3, \mathrm{P}=0.002$ )

\section{Prediction of postoperative atrial fibrillation}

Univariate analyses showed that body mass index, CRP/Albumin ratio, N/L ratio, $\mathrm{P} / \mathrm{L}$ ratio, $\mathrm{CRP}$, albumin, diabetes mellitus, hypertension, congestive heart failure, peripheral vascular disease, low left ventricle ejection fraction, advanced age, fasting glucose level, 24-hour drainage amount, cardiopulmonary bypass time and male gender were significantly associated with a higher risk of development of POAF (Table 2). The correlation analysis revealed that CAR exhibited a weak correlation between CAR and N/L ratio $(\mathrm{r}=0.147, \mathrm{P}<0.001)$ and $\mathrm{P} / \mathrm{L}$ ratio $(\mathrm{r}=0.226, \mathrm{P}=$ 0.001). To determine the independent predictors for

TABLE 2. FACTORS THAT WERE FOUND TO BE INDEPENDENTLY ASSOCIATED WITH THE DEVELOPMENT OF POSTOPERATIVE ATRIAL FIBRILLATION IN UNIVARIATE AND MULTIVARIATE LOGISTIC REGRESSION ANALYSIS MODELS.

\begin{tabular}{l|l|l|l|l|l|l} 
& $\begin{array}{l}\text { Unadjusted } \\
\text { Odds Ratio }\end{array}$ & $\begin{array}{l}\text { Confidence } \\
\text { Interval }\end{array}$ & P-value & $\begin{array}{l}\text { Adjusted Odds } \\
\text { Ratio }\end{array}$ & $\begin{array}{l}\text { Confidence } \\
\text { Interval }\end{array}$ & P value \\
\hline Diabetes mellitus & 1.67 & $1.11-2.53$ & 0.014 & & & \\
\hline Hypertension & 3.075 & $1.69-5.58$ & $<0.001$ & & & \\
\hline Congestive heart failure & 4.85 & $2.44-9.61$ & $<0.001$ & & & \\
\hline Peripheral vascular disease & 1.67 & $1.07-2.59$ & 0.02 & & & \\
\hline BMI & 0.96 & $0.92-1.00$ & 0.06 & & & \\
\hline Fasting glucose level & 1.006 & $1.004-1.009$ & $<0.001$ & 1.01 & $1.00-1.01$ & $<0.001$ \\
\hline Age & 1.06 & $1.04-1.08$ & $<0.001$ & 1.12 & $1.07-1.17$ & $<0.001$ \\
\hline Male gender & 2.015 & $1.22-3.33$ & 0.006 & 3.32 & $1.39-7.90$ & 0.007 \\
\hline 24-hour drainage & 1.002 & $1.001-1.003$ & 0.004 & 1.004 & $1.002-1.005$ & $<0.001$ \\
\hline Left ventricle ejection fraction & 0.93 & $0.91-0.95$ & $<0.001$ & 0.90 & $0.87-0.94$ & $<0.001$ \\
\hline Cardiopulmonary bypass time & 1.007 & $1.00-1.01$ & 0.04 & & & \\
\hline CRP to Albumin Ratio & 1.575 & $1.40-1.76$ & $<0.001$ & 1.82 & $1.53-2.16$ & $<0.001$ \\
\hline N to L ratio & 1.040 & $0.89-1.08$ & 0.06 & & & \\
\hline P to L ratio & 1.01 & $1.00-1.03$ & 0.04 & & & \\
\hline CRP & 1.12 & $1.09-1.15$ & $<0.001$ & & & \\
\hline Albumin & 0.395 & $0.21-0.71$ & 0.002 & & & \\
\hline
\end{tabular}


the development POAF, a multivariate binary logistic regression analysis was carried out. The univariate analysis of all parameters associated with new-onset AF except NLR, PLR, CRP and albumin showed that fasting glucose level (OR: 1.01; 95\% CI: 1.00-1.01, P $<0.001$ ), age (OR: 1.12; 95\% CI: 1.07-1.17, P <0.001), left ventricle ejection fraction (OR: 0.90; 95\% CI: 0.87-0.94, $\mathrm{P}<0.001$ ), male gender (OR: 3.32; 95\% CI: 1.39-7.90, $\mathrm{P}=0.007$ ), 24-hour drainage amount (OR: 1.004; 95\% CI: 1.002-1.005, P <0.001), CAR (OR: 1.82; 95\% CI: 1.53-2.16, $\mathrm{P}<0.001)$ remained as independent factors for incident AF (Table 2). ROC curve analysis showed that CAR (C-statistic: 0.75; 95\% CI: 0.71$0.79, \mathrm{p}<0.001)$ was a significant predictor of POAF (Figure 1). We calculated that a cut-off point of 3.5 for CAR could estimate the presence of POAF with a sensitivity of $58 \%$ and $92 \%$. We performed a pairwise comparison of the ROC curves and observed that the predictive value of the CAR with regard to POAF development was superior to that of albumin and CRP (DeLong method, $\mathrm{AUC}_{\mathrm{CAR}}$ versus $\mathrm{AUC}_{\mathrm{CRP}}$ $\mathrm{z}$ test $=3.592, \mathrm{p}=0.0003 ; \mathrm{AUC}_{\mathrm{CAR}}$ versus $\mathrm{AUC}_{\text {Albumin }}$ $\mathrm{z}$ test $=3.927, \mathrm{p}=0.0001 ; \mathrm{AUC}_{\text {albumin }}$ versus $\mathrm{AUC}_{\mathrm{CRP}} \mathrm{z}$ test $=3.594, p=0.0003$ )

\section{DISCUSSION}

Main findings

The main findings of this observational study are as follows: (i) elevated CAR, high fasting glucose level, advanced age, male gender, first 24-hour drainage amount, and lower LVEF values are significantly associated with POAF; (ii) a CAR value of more than 3.5 and was found to be a predictor of POAF; and (iii) NLR and PLR were higher in patients with POAF compared to without POAF.

Mechanism of postoperative atrial fibrillation In the postoperative period, $\mathrm{AF}$ is thought to be triggered by electrophysiological abnormalities, which

FIGURE 1. RECEIVER OPERATING CHARACTERISTICS (ROC) CURVE ANALYSIS OF THE VARIABLES.

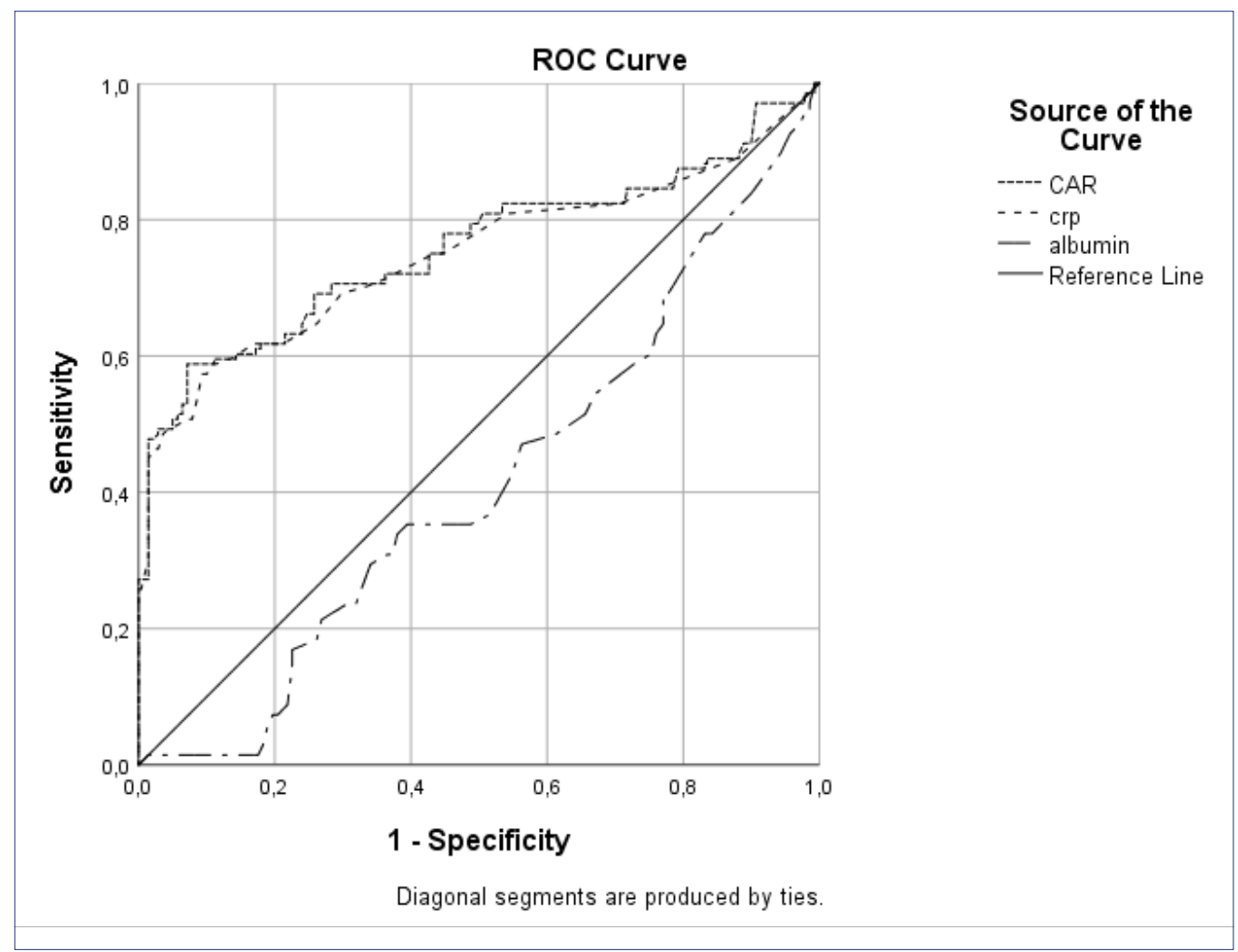

\begin{tabular}{l|l|l|l|l|l|l}
\hline & C-statistic & \multicolumn{2}{l}{ 95\% Confidence Interval } & \multicolumn{2}{l}{ P-value } & \multicolumn{2}{l}{ Cut-off value } & \multicolumn{2}{l}{ Sensitivity } \\
\hline CAR & 0,758 & $0,713-0,798$ & $<0.001$ & $>3.5$ & 58 & 92 \\
\hline albumin & 0,587 & $0,538-0,635$ & 0.0031 & $\leq 4.31$ & 98 & 17 \\
\hline crp & 0,748 & $0,704-0,789$ & $<0.001$ & $>12.7$ & 58 & 89 \\
\hline
\end{tabular}

CAR: $C$ reactive protein to albumin ratio; CRP: C reactive protein; pairwise comparision of variables: (by DeLong method, $A U C$ CAR versus AUC CRP $z$ test $=3.592, p=0.0003$; AUC CAR versus AUC Albumin $z$ test $=3.927, p=0.0001$; AUC albumin versus AUC CRP $z$ test $=3.594, p=0.0003$ ). 
frequently happen in patients who have an abnormal atrial substrate. ${ }^{6}$ High catecholamine state ${ }^{7}$ and postoperative inflammation ${ }^{6}$ are thought to have lay a key role.

Inflammation and postoperative atrial fibrillation

As bypass surgery may induce oxidative stress and inflammation, these processes may be responsible for complications after cardiac surgery, including POAF. ${ }^{6}$ Several studies have suggested a strong link between inflammation and atrial fibrillation. ${ }^{12}$ Increased inflammatory processes are also suggested to be associated with new-onset AF after coronary artery bypass grafting. Lo et al. ${ }^{13}$ showed that CRP level $>3 \mathrm{mg} / \mathrm{L}$ was associated with an increased risk of AF in patients undergoing CABG. Supporting this, high CRP levels were associated with the development of new-onset AF following CABG in the present study. Serum CRP, an acute-phase protein, is released from the liver in response to inflammation and has been associated with poor prognosis for patients with coronary artery disease (CAD).${ }^{14}$ De Lorenzo et al..$^{15}$ showed that high preoperative CRP levels were associated with in-hospital mortality after CABG. Kinoshita et al. ${ }^{16}$ reported that preoperative CRP levels were independently associated with the development of AF after isolated off-pump CABG. Although the relationship between CRP and CAD is not fully understood, multiple mechanisms may be suggested. CRP has been shown to disturb the endothelial progenitor cells, increase the prothrombotic status, activate the complement system, and play a role in the uptake of low-density lipoprotein-C by macrophages and convert them into foam cells. ${ }^{17}$ Additionally, a strong association between AF and inflammation has been reported..$^{1,3}$ The most important pathophysiological changes described in previous studies include the presence of inflammatory infiltrates, myocyte necrosis, and fibrosis in atrial biopsies and the presence of circulating autoantibodies against myosin heavy chain. ${ }^{1,6}$ Serum albumin, a negative acute-phase protein, is released from the liver in response to inflammation, and decreased albumin levels have been associated with adverse cardiovascular events. ${ }^{18}$ Additionally, albumin is not solely associated with inflammation but also with blood viscosity and endothelial functions. Decreased albumin levels increase blood viscosity and platelet activation and worsen endothelial functions. ${ }^{19}$ These factors may explain the association between CRP, albumin levels, and POAF. In the present study, we showed that increased CRP levels, decreased albumin levels, and increased CAR were associated with POAF.

The N/L ratio is a widely available marker of inflammation that is cheap and easy to obtain and can be used in the risk classification of patients with several cardiovascular diseases in addition to the traditionally used markers. It is also considered to be a good and powerful predictor of mortality and morbidity in patients undergoing CABG surgery. ${ }^{20}$ In this setting, Gibson et al. ${ }^{21}$ showed that high preand postoperative N/L ratios were associated with the development of AF after CABG. Corroborating this, preoperatively the N/L ratio was found to be higher in patients with new-onset AF following CABG in the present study. Additionally, platelets are a source of inflammatory mediators. Increased platelet levels were reported to be associated with adverse cardiovascular outcomes. ${ }^{22} \mathrm{~A}$ high $\mathrm{P} / \mathrm{L}$ ratio, defined as a biomarker of inflammation, was reported to be associated with POAF in patients undergoing CABG. ${ }^{23}$ In the current study, the preoperative $\mathrm{P} / \mathrm{L}$ ratio was also higher in patients with new-onset AF following CABG. Another important finding of the present study is the association of advanced age with the development of POAF. The inflammatory response can increase with advanced age via the activity of the mitochondrial adaptor protein p66 (Shc) and sirtuins, which are a family of deacetylase enzymes. ${ }^{24}$ Previous studies have shown that hypertension, diabetes mellitus, obesity, valvular disease, increased age, and left atrial characteristics such as size, volume, and scarring can contribute to the development of POAF. ${ }^{25}$ Supporting this, the incidence of hypertension, diabetes mellitus, congestive heart failure, and peripheral arterial disease history was higher in patients with POAF compared to patients without POAF in the present study.

In recent studies, several factors have been mentioned, including predisposing ones, such as obesity, diabetes mellitus, hypertension, advanced age, metabolic syndrome, intraoperative ones, such as surgical methods, off-pump surgery, and acute volume changes, and postoperative ones, such as hypotension and volume overload. ${ }^{5-8}$ Our data showed that advanced age, obesity, hypertension, male gender, diabetes mellitus, congestive heart failure, and peripheral vascular disease were more frequently present in patients with POAF than in those without POAF. 
Additionally, patients with POAF had a longer hospitalization period, cardiopulmonary bypass time, and 24-hour drainage amount than patients without POAF. Multivariate analysis showed that fasting glucose level, advanced age, male gender, 24-hour drainage, and left ventricle ejection fraction were independent predictors of POAF.

Combining albumin and CRP into a single index was demonstrated to be associated with adverse events in coronary artery disease. ${ }^{9,10}$ We showed here that an increased CRP/albumin ratio indicates a higher inflammatory state and may be superior to CRP and albumin alone in determining POAF. To our knowledge, this is the first study to evaluate the relationship between CAR and POAF. Our results suggest that elevated CAR in patients undergoing CABG was an independent predictor of new-onset $\mathrm{AF}$ after $\mathrm{CABG}$, and the predictive accuracy of CAR was better than that of CRP and albumin level, as per the comparison of the ROC curves.

\section{Study limitations}

Importantly, this study has some limitations. First, it has a retrospective design, a relatively small sample size, and engaged in a single-center experience. Second, we evaluated only baseline CRP and albumin levels before CABG and the changes that would be observed by consecutive measurements, such as in the postoperative period, that may have an additional predictive value. Third, the data acquired did not let us appraise the prognostic value of CAR on adverse cardiovascular outcomes, since we recorded only limited volume and event rate values.

\section{CONCLUSIONS}

This study demonstrated that decreased LVEF, elevated CAR, male gender, advanced age, 24-hour drainage, and increased fasting glucose level were independent predictors for the development of POAF. We also observed that the predictive accuracy of CAR for the development of POAF was better than that of NLR or PLR.

This study revealed that CAR was statistically significantly associated with POAF. CAR is an easy to obtain, easily measurable, and cheap parameter that can predict the development of POAF. This parameter can be part of the preoperative evaluation to identify patients who may develop AF.

\section{Sources of funding \\ None. \\ Conflict of interest}

None.

The study was conducted in the Suleyman Demirel University Education and Research Hospital in Isparta, Turkey

\section{RESUMO}

OBJETIVO: Este estudo teve como objetivo investigar o valor preditivo da recém-definida relação entre Proteína C-Reativa (PCR) e Albumina (CAR) na determinação do desenvolvimento de Fibrilação Atrial (FA) em comparação com outros marcadores inflamatórios, como proporção de Neutrófilos para Linfócitos $(N / L)$ e relação Plaquetas/Linfócitos $(P / L)$ em pacientes submetidos à Cirurgia de Revascularização do Miocárdio (CRM).

MÉTODOS: A população deste estudo observacional foi composta por 415 pacientes submetidos à cirurgia de revascularização do miocárdio. A coorte do estudo foi subdividida em dois grupos de acordo com o desenvolvimento da FA. Contagens sanguíneas completas, PCR sérica e albumina sérica foram obtidas antes da CRM. Os valores de CAR, relação $N / L$ e relação $P / L$ foram calculados. Os preditores de FA pós-operatória foram determinados por análise de regressão logística múltipla.

RESULTADOS: Durante o acompanhamento, 136 pacientes (32,8\%) desenvolveram FA pós-operatória. Com análise de regressão logística múltipla, foram determinados os fatores de risco para FA pós-operatória: glicemia de jejum (OR: 1,01; IC 95\%: 1,00-1,01, p<0,001), idade (OR: 1,12; IC 95\%: 1,07-1,17, p<0,001), fração de ejeção do ventrículo esquerdo (OR: 0,90; IC 95\%: 0,87-0,94, p<0,001), sexo masculino (OR: 3,32; IC 95\%: 1,39-7,90, $p=0,007$ ), quantidade de drenagem de 24 horas (OR: 1,004; IC 95\%: 1,002-1,005, $p<0,001)$, CAR (OR: 1,82; IC 95\%: 1,53-2,16, $p<0,001$ ). A análise da curva de características operacionais do receptor mostrou que o CAR (estatística C: 0,75; IC 95\%: 0,71-0,79, $p<0,001$ ) foi um preditor significativo de FA.

CONCLUSÃO: O novo marcador inflamatório CAR é confiável para prever o desenvolvimento de FA após a operação de revascularização miocárdica.

PALAVRAS-CHAVE: Proteína C. Albuminas. Fibrilação atrial. Revascularização miocárdica. Ponte de artéria coronária. 


\section{REFERENCES}

1. Ozaydin M. Atrial fibrillation and inflammation. World / Cardiol. 2010;2(8):243-50

2. Ren Y, Zeng RX, Li IJ, Guo LH, He DY, Li Y, et al. Relation of C-reactive protein and new-onset atrial fibrillation in patients with acute myocardial infarction: a systematic review and meta-analysis. Int J Cardiol. 2015;190:268-70.

3. Aviles RJ, Martin DO, Apperson-Hansen C, Houghtaling PL, Rautaharju $P$, Kronmal RA, et al. Inflammation as a risk factor for atrial fibrillation. Circulation. 2003;108(24):3006-10.

4. Gedikli O, Dogan A, Altuntas I, Altinbas A, Ozaydin M, Akturk O, et al. Inflammatory markers according to types of atrial fibrillation. Int J Cardiol. 2007;120(2):193-7.

5. Ucar HI, Tok M, Atalar E, Dogan OF, Oc M, Farsak B, et al. Predictive significance of plasma levels of interleukin-6 and high-sensitivity $C$-reactive protein in atrial fibrillation after coronary artery bypass surgery. Heart Surg Forum. 2007;10(2):E131-5.

6. Ozaydin M, Peker O, Erdogan D, Akcay S, Yucel H, Icli A, et al. Oxidativestatus, inflammation, and postoperative atrial fibrillation with metoprolol vs carvedilol or carvedilol plus $\mathrm{N}$-acetyl cysteine treatment. Clin Cardiol. 2014;37(5):300-6.

7. Thompson AE, Hirsch GM, Pearson G]. Assessment of new onset postcoronary artery bypass surgery atrial fibrillation: current practice pattern review and the development of treatment guidelines. I Clin Pharm Ther. 2002;27(1):21-37.

8. Emren V, Aldemir M, Duygu H, Kocabaş U, Tecer E, Cerit L, et al. Usefulness of HATCH score as a predictor of atrial fibrillation after coronary artery bypass graft. Kardiol Pol. 2016;74(8):749-53.

9. Kalyoncuoglu M, Durmus G. Relationship between C-reactive protein-to-albumin ratio and the extent of coronary artery disease in patients with non-ST-elevated myocardial infarction. Coron Artery Dis. 2020;31(2):130-6.

10. Rencuzogullari I, Karabağ Y, Çağdaş M, Karakoyun S, Seyis S, Gürsoy MO, et al. Assessment of the relationship between preprocedural C-reactive protein/albumin ratio and stent restenosis in patients with ST-segment elevation myocardial infarction. Rev Port Cardiol. 2019;38(4):269-77.

11. Ozaydin M, Icli A, Yucel H, Akcay S, Peker O, Erdogan D, et al. Metoprolol vs. carvedilol or carvedilol plus $\mathrm{N}$-acetyl cysteine on post-operative atrial fibrillation: a randomized, double-blind, placebo-controlled study. Eur Heart J. 2012;34(8):597-604.

12. Bas HA, Aksoy F, Icli A, Varol E, Dogan A, Erdogan D, et al. The association of plasma oxidative status and inflammation with the development of atrial fibrillation in patients presenting with ST elevation myocardial infarction. Scand J Clin Lab Invest. 2017;77(2):77-82.
13. Lo B, Fijnheer R, Nierich AP, Bruins P, Kalkman CJ. C-reactive protein is a risk indicator for atrial fibrillation after myocardial revascularization. Ann Thorac Surg. 2005;79(5):1530-5.

14. Blake G), Ridker PM. C-reactive protein and other inflammatory risk markers in acute coronary syndromes. J Am Coll Cardiol. 2003;41(4 Suppl S):37S-42S.

15. De Lorenzo A, Pittella F, Rocha A. Increased preoperative C-reactive protein levels are associated with inhospital death after coronary artery bypass surgery. Inflammation. 2012;35(3):1179-83.

16. Kinoshita T, Asai T, Takashima N, Hosoba S, Suzuki T, Kambara A, et al. Preoperative $\mathrm{C}$-reactive protein and atrial fibrillation after off-pump coronary bypass surgery. Eur J Cardiothorac Surg. 2011;40(6):1298-303.

17. Bisoendial RJ, Boekholdt SM, Vergeer M, Stroes ES, Kastelein JJ. C-reactive protein is a mediator of cardiovascular disease. Eur Heart J. 2010;31(17):2087-91.

18. Wada H, Dohi T, Miyauchi K, Doi S, Naito R, Konishi H, et al. Independent and combined effects of serum albumin and C-reactive protein on longterm outcomes of patients undergoing percutaneous coronary intervention. Circ |. 2017;81(9):1293-300.

19. Joles JA, Willekes-Koolschijn N, Koomans HA. Hypoalbuminemia causes high blood viscosity by increasing red cell lysophosphatidylcholine. Kidney Int. 1997;52(3):761-70.

20. Parlar H, Şaşkın H. Are pre and postoperative platelet to lymphocyte ratio and neutrophil to lymphocyte ratio associated with early postoperative $A K I$ following CABG? Braz | Cardiovasc Surg. 2018;33(3):233-41.

21. Gibson PH, Cuthbertson BH, Croal BL, Rae D, El-Shafei H, Gibson G, et al. Usefulness of neutrophil/lymphocyte ratio as predictor of new-onset atrial fibrillation after coronary artery bypass grafting. Am | Cardiol. 2010;105(2):186-91.

22. Azab B, Shah N, Akerman M, McGinn JT Jr. Value of platelet/lymphocyte ratio as a predictor of all-cause mortality after non-ST-elevation myocardial infarction. J Thromb Thrombolysis. 2012;34(3):326-34.

23. Gungor H, Babu AS, Zencir C, Akpek M, Selvi M, Erkan MH, et al. Association of preoperative platelet-to-lymphocyte ratio with atrial fibrillation after coronary artery bypass graft surgery. Med Princ Pract. 2017;26(2):164-8.

24. Camici GG, Savarese G, Akhmedov A, Lüscher TF. Molecular mechanism of endothelial and vascular aging: implications for cardiovascular disease. Eur Heart ). 2015;36(48):3392-403.

25. Maesen B, Nijs J, Maessen J, Allessie M, Schotten U. Post-operative atrial fibrillation: a maze of mechanisms. Europace. 2011;14(2):159-74. 